\title{
Analysis for the Effect of Roof Greening in Warehouse by Mean of Simulation
}

\author{
Noriko TAKAhashi ${ }^{1}$, Hiroshige Nishina ${ }^{1}$, Kotaro TAKAYAma ${ }^{1}$, Saori Futagami ${ }^{1}$, \\ Takashi KAMURA $^{2}$ and Teruhisa NAKAHARA ${ }^{2}$ \\ ${ }^{\prime}$ Faculty of Agriculture, Ehime University, 3-5-7 Tarumi, Matsuyama, Ehime 790-8566, Japan \\ ${ }^{2}$ Bioresources Research Center, Kyushu Electric Power CO., 1-10-1, Takagise Higashi, Saga 849-0922, Japan
}

(Received December 26, 2012; Accepted May 30, 2013)

\begin{abstract}
Roof greening in warehouse is expected not only to improve the environment but also to reduce the heat island effects by evapotranspiration from the soil and plants. Effects of roof greening on room air temperature in warehouse and cooling load in summer were investigated using simulation model. In this study, two types of roof greening were assumed, roof greening with soil (greening type 1) and without soil (greening type 2). Our results showed that room air temperature in warehouse was decreased by $18.1^{\circ} \mathrm{C}$ for greening type 1 and $9.5^{\circ} \mathrm{C}$ for greening type 2 compared with no roof greening. In greening type 1, the room air temperature was decreased with increasing the coefficient of transpiration from the plants. The maximum room air temperature was decreased with increasing the light interception ratio and decrease in room air temperature with increasing light interception ratio in greening type 2 was larger than that in greening type 1 . Daily cooling load with greening type 1 was lower than that with greening type 2 . Electricity cost for air-conditioning in summer was reduced by 135 yen for greening type 1 and 63 yen for greening type 2 compared with that for no greening when set temperature for cooling was $26^{\circ} \mathrm{C}$. These results suggested that roof greening with soil can maintain lower air temperature in warehouse and save more cooling load than that without soil due to the latent heat with evaporative cooling from the soil.
\end{abstract}

Keywords : cooling load, heat balance, light interception ratio, roof greening, temperature rise control

\section{INTRODUCTION}

Greening on roof or wall has advantages of landscape and urban environment improvements and air purification with trees (Miyagawa and Kawaguchi, 2002; Iijima, 2008; Santamouris, 2012). It has been reported that heat-island effect can be suppressed by covering on roof and wall with green and decreased the surface temperature by evapotranspiration of plants and soil (Nojima et al., 1995; Yamada, 2008). Therefore, greening on roof or wall is considering the idea as an effective strategy to suppress the heat-island effect and reduce global warming.

Furthermore, greening on roof or wall is expected to contribute the energy saving for cooling and heating of the building with solar radiation interception and heat insulation. Especially non-residential buildings such as factories and warehouses have large roof areas with low heat insulating properties due to the building cost saving. During the day, roof absorbs solar radiation and it is easy to become high air temperature in the room. In summer, cooling load for air-conditioning is expected to increase because the heat transferred from the roof fills the headspace of the room with warm air. Therefore, roof greenings on factories and warehouse are expected to alleviate the heat radiation from the heated roof.

When the factory is built, greening, production and environmental facilities space-area rations to the lot area are prescribed under the Factory Location Act from the
Ministry of Economy, Trade and Industry in Japan. According to a revision of Factory Location Act in March 2004, greening area on the building that is included in facilities is allowed to regard as greening area up to $25 \%$. This helps to put the land to other use. Thus the greening on factories and warehouse is expected for effective utilization of land.

According to the statistical data from Ministry of Land, Infrastructure, Transport and Tourism in August 2011, plant varieties for roof greening are reported lawn (22.6\%), sedum $(22.2 \%)$ and other grass $(10.3 \%)$. These varieties can be separated greening with and without the soil. Yamaguchi et al. (2005) reported that heat insulation effect of roof greening was varied with plant varieties and with or without soil. However, little is known that the effects of roof greening with or without soil on cooling load for air-conditioning in summer.

The objective of this research is to evaluate the effects of two roof greening systems with and without soil on air temperature and cooling load in warehouse in summer using a simulation model.

\section{MATERIALS AND METHODS}

\section{Roof greening system}

The roof greening system was applied to warehouse with a height of $5 \mathrm{~m}$. The warehouse consists of soil and cement for floor and galvalume steel plate and thermal insulator for roof. The simulation model area was $1 \mathrm{~m}^{2}$ from

Corresponding author: Noriko Takahashi, fax: $+81-89-946-9761$, e-mail : takahashi.noriko.mm@ehime-u.ac.jp 
the center of the floor. As shown in Fig. 1, greening system consists of polyvinyl chloride, soil, and plants for "greening type 1", and net and climbing plants for "greening type 2". The light interception ratio which the plants block out the sun was used for the evaluation of differences in planting rate and plant growth rate.

For the roof, temperature points were separated into two layers, galvalume steel plate $(0.6 \mathrm{~mm})$ and thermal insulator $(4 \mathrm{~mm})$. For the floor, temperature points were set to six layers for cement $(10 \mathrm{~mm}, 20 \mathrm{~mm}, 30 \mathrm{~mm}, 40 \mathrm{~mm}$, $50 \mathrm{~mm}$, and $60 \mathrm{~mm})$ and three layers for soil $(60 \mathrm{~mm} \times 3)$, as shown in Fig. 2. For the greening system in greening type 1 , temperature points were separated five layers for soil $(10 \mathrm{~mm} \times 5)$ and one layer for polyvinyl chloride (5 $\mathrm{mm}$ ). An air temperature point was set in the room. Temperature point was located from the indoor to outdoor and the heat flow from top-to-bottom was defined as plus.

Simulation model

Flow chart of simulation is shown in Fig. 3. Programming was developed with Microsoft Visual Studio 2010 Software. Simulation model computed every 1/10,000

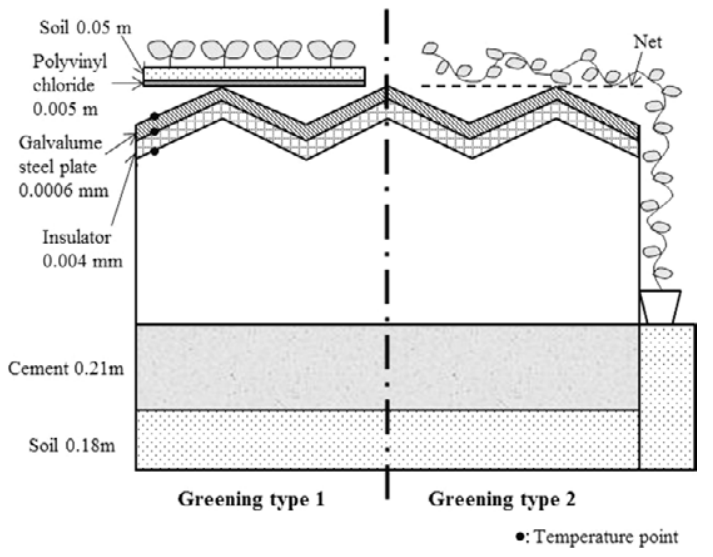

Fig. 1 Schematic diagram of roof greening. Greening type 1 consists of plants with soil. Greening type 2 consists of plants without soil. Temperature points $(\mathbf{)}$ ) were set for 3 in the roof.

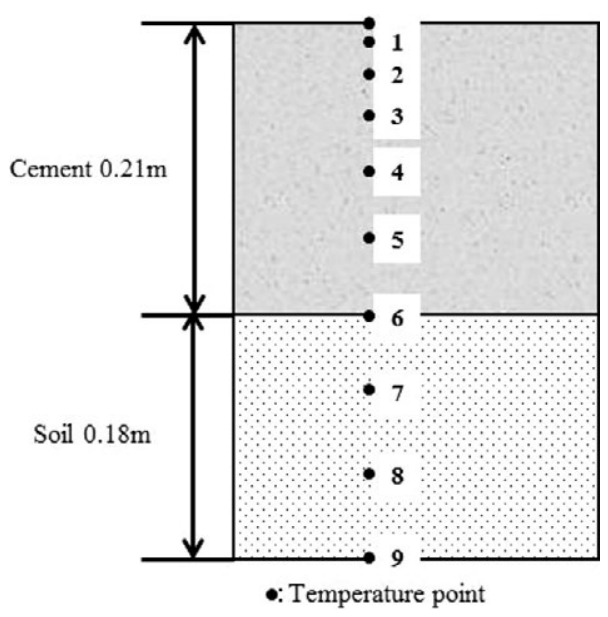

Fig. 2 Schematic diagram of floor in warehouse. Floor consists of cement and soil. Temperature points ( ) were set for 10 in the floor. The numbers of temperature points were assigned from the room inside to outside. min after reading the valuables, weather data, and input default. Then, the calculated value was conserved for one min and computed every one min. Simulation model was calculated for 10 days and output the data on the 10th.

In this study, the weather data from the typical sunny day in summer was used and the date was on July 10th. The atmospheric transmittance was defined 0.7. The direct solar radiation and sky radiation on inclined surface was determined with sun's altitude and azimuth from the time and date. The global solar radiation was calculated from the direct radiation and sky radiation.

Heat balance $Q\left(\mathrm{~J} \mathrm{~h}^{-1}\right)$ of roof, floor, and indoor air was calculated, respectively. Heat conductance $c\left(\mathrm{~J} \mathrm{~m}^{-2}\right.$ $\left.{ }^{\circ} \mathrm{C}^{-1} \mathrm{~h}^{-1}\right)$ and heat transfer $q\left(\mathrm{~J} \mathrm{~h}^{-1}\right)$ between temperature points $T_{i}$ and $T_{i+1}$ are given by

$$
\begin{aligned}
& c=\lambda / l \\
& q=c \times\left(T_{i}-T_{i+1}\right) \times A
\end{aligned}
$$

where $\lambda$ is heat conductivity $\left(\mathrm{J} \mathrm{m}^{-1}{ }^{\circ} \mathrm{C}^{-1} \mathrm{~h}^{-1}\right), l$ is distance between temperature points for $T_{i}$ and $T_{i+1}(\mathrm{~m})$, and $A$ is area $\left(\mathrm{m}^{2}\right)$.

Sensible heat of greening soil $q_{s}\left(\mathrm{~J} \mathrm{~h}^{-1}\right)$, radiation exchange $q_{r}\left(\mathrm{~J} \mathrm{~h}^{-1}\right)$, latent heat of evapotranspiration from the soil and plants surface $q_{e}\left(\mathrm{~J} \mathrm{~h}^{-1}\right)$, and solar absorption $R(\mathrm{~J}$ $\mathrm{h}^{-1}$ ) are given by

$$
\begin{aligned}
& q_{s}=\alpha \times\left(T_{i}-T_{\text {out }}\right) \times A \\
& q_{r}=\sigma \times \varepsilon \times\left(T_{i}+273\right)^{4} \times A-\varepsilon_{a} \times \varepsilon \times A \\
& q_{e}=\alpha_{w} \times\left(C_{p}-C_{a}\right) \times A \times C_{t r} \times 583 \times 1000 \times 4.186 \\
& R=R_{h} \times a \times(1-L) \times A
\end{aligned}
$$

where $\alpha$ is coefficient of sensible heat transfer $\left(\mathrm{J} \mathrm{m}^{-2}{ }^{\circ} \mathrm{C}^{-1}\right.$ $\left.\mathrm{h}^{-1}\right), T_{\text {out }}$ is ambient air temperature $\left({ }^{\circ} \mathrm{C}\right), \sigma$ is Stefan-Boltzmann's constant $\left(\mathrm{J} \mathrm{m}^{-2} \mathrm{~h}^{-1} \mathrm{~K}^{-4}\right), \varepsilon$ is emittance, $\varepsilon_{a}$ is downward atmospheric radiation $\left(\mathrm{J} \mathrm{m}^{-2} \mathrm{~h}^{-1}\right), \alpha_{w}$ is coefficient of water vapor transfer at the plant leaf surface $\left(\mathrm{m} \mathrm{h}^{-1}\right), C_{p}$ is

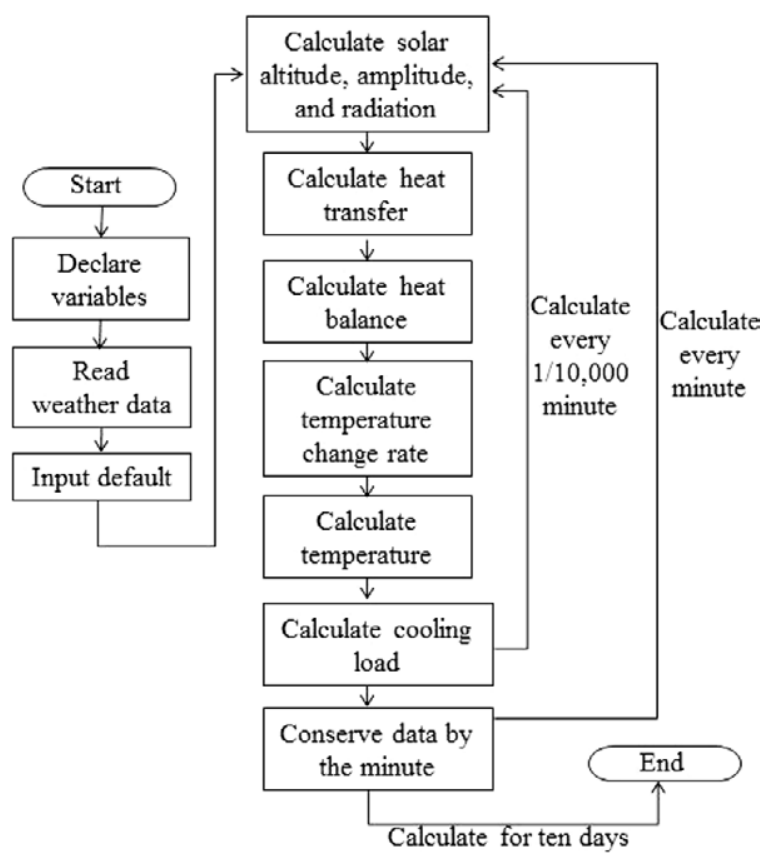

Fig. 3 Flow chart of simulation for roof greening evaluation in warehouse in summer. 
water vapor content in the plant $\left(\mathrm{kg} \mathrm{m}^{-3}\right), C_{a}$ is atmospheric water vapor content $\left(\mathrm{kg} \mathrm{m}^{-3}\right), C_{t r}$ is coefficient of transpiration from the plants, $a$ is solar absorptance, and $L$ is light interception ratio.

Heat balance on the soil surface for greening $Q_{s}(\mathrm{~J}$ $\left.\mathrm{h}^{-1}\right)$ is given by

$$
Q_{s}=-q+R-q_{s}-q_{r}-q_{e}
$$

Heat balance $Q\left(\mathrm{~J} \mathrm{~h}^{-1}\right)$ of roof, floor, and indoor air was calculated as well as $Q_{s}$, respectively.

Temperature change rate $D t\left({ }^{\circ} \mathrm{C} \mathrm{h}^{-1}\right)$ at each temperature point and temperature $T\left({ }^{\circ} \mathrm{C}\right)$ at the time $t$ were given by

$$
\begin{aligned}
& D t=Q / C \\
& T=\int_{0}^{t} D t d t+T_{0}
\end{aligned}
$$

where $C$ is thermal capacity $\left(\mathrm{J} \mathrm{h}^{-1}\right)$ and $T_{0}$ is initial temperature $\left({ }^{\circ} \mathrm{C}\right)$.

Economical evaluation of roof greening for cooling

The cooling load and electricity cost with roof greening for air-conditioning in summer were calculated using a simulation model. The cooling load $Q_{\text {cool }}\left(\mathrm{J} \mathrm{h}^{-1}\right)$ was examined at the set temperature of air-conditioning for 24,26 , and $28^{\circ} \mathrm{C}$ and given by

$$
Q_{\text {cool }}=\left(T_{a}-T_{s}\right) \times c_{p} \times V
$$

where $T_{a}$ is room air temperature $\left({ }^{\circ} \mathrm{C}\right), T_{s}$ is set temperature for air-conditioning $\left({ }^{\circ} \mathrm{C}\right), c_{p}$ is volumetric specific heat of air $\left(\mathrm{J} \mathrm{m}^{-3}{ }^{\circ} \mathrm{C}^{-1}\right)$, and $V$ is volume $\left(\mathrm{m}^{3}\right)$. If the room air temperature after calculating with $1 / 10,000$ min exceeds the set temperature, the heat quantity required to reduce the room air to the set temperature was determined.

Daily cooling load was calculated with integrating cooling load from midnight. Electric energy was determined from the cooling load assuming the coefficient of performance (COP) of air-conditioning was 5. Electricity cost was converted $1 \mathrm{kWh}$ of an electric energy to 20 yen.

\section{RESULTS AND DISCUSSION}

\section{Evaluation of simulation model}

Daily heat flux changes in the floor without roof greening are shown in Fig. 4. Figure 5 shows daily heat flux changes in the floor without greening when airconditioning was turning on with set temperature of $26^{\circ} \mathrm{C}$. In these figures, the numbers were assigned from the room inside to outside and the heat flow from top to bottom was defined plus. Since the heat flows from the room to the bottom, the air temperature change at the bottom had the time-delay and the amplitude became smaller with the increase of number. The heat flux with air-conditioning was smaller than that without air-conditioning because the air temperature in the room was maintained. These results suggested that the simulation model can be used for the evaluation of the heat flow in warehouse.

Effect of roof greening on room air temperature

Diurnal changes of room air temperature with two roof greening types (light interception ratio $=0.6$ ) and no greening are shown in Fig. 6. The greening type 1 consists of

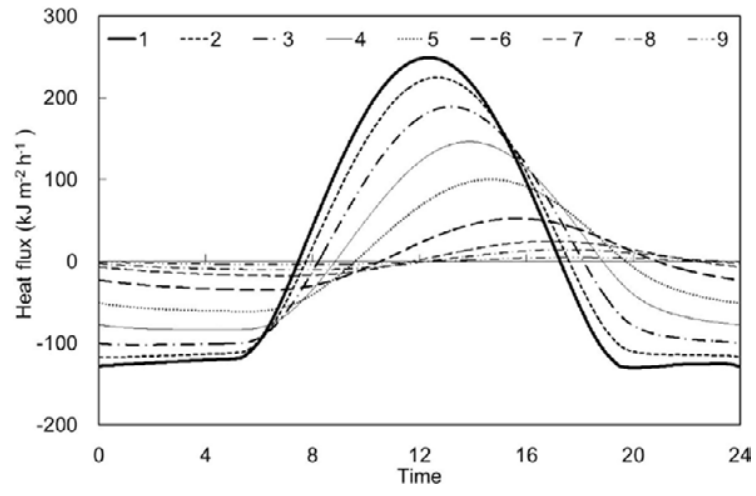

Fig. 4 Diurnal heat flux changes in the floor without roof greening when air-conditioning was turning off. Heat fluxes were calculated at nine points in the floor. The numbers were assigned from the room inside to outside (refer to Fig. 2) and the heat flow from top to bottom was defined plus.

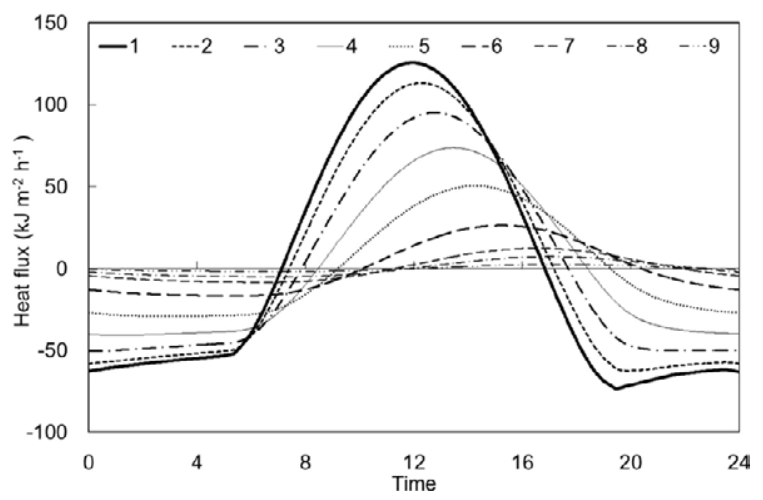

Fig. 5 Diurnal heat flux changes in the floor without greening when air-conditioning was turning on. The set temperature for air-conditioning was adjusted at $26^{\circ} \mathrm{C}$. Heat fluxes were calculated at nine points in the floor. The numbers were assigned from the room inside to outside (refer to Fig. 2) and the heat flow from top to bottom was defined plus.

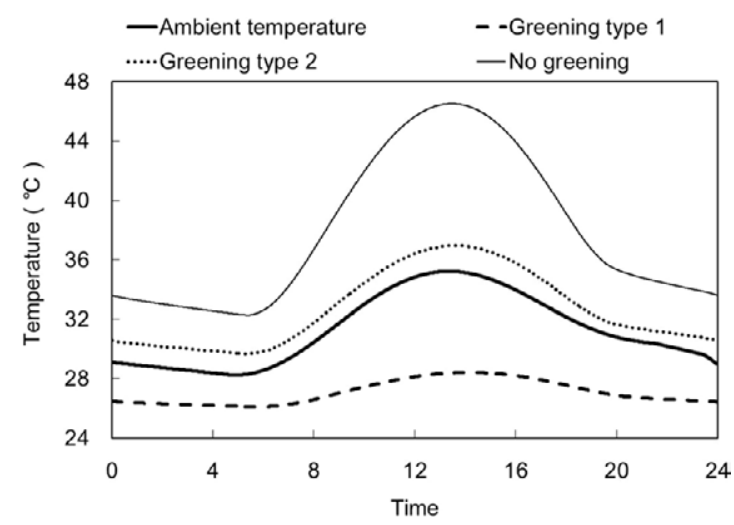

Fig. 6 Diurnal air temperature changes of ambient and room with two greening types (light interception rate $=0.6$ ) and no greening. Greening type 1 consists of plants with soil. Greening type 2 consists of plants without soil.

plant and soil and greening type 2 was from plant without soil. The maximum room air temperatures were about 46.5 ${ }^{\circ} \mathrm{C}$ for no greening, $28.4^{\circ} \mathrm{C}$ for roof greening type 1 , and $37.0^{\circ} \mathrm{C}$ for greening type 2 . Satou et al. (2006) reported 
that the roof greening with sedum plate could reduce the room air temperature about $13^{\circ} \mathrm{C}$ compared with no greening. Tachibana et al. (2010) found that temperature with roof greening climbing plants was about $10^{\circ} \mathrm{C}$ lower than that without plants. These results suggested that the roof greening with soil can maintain lower room air temperature than that without soil. In roof greening with soil, it was reported that the surface temperature on the soil was decreased with increasing the water content in the soil (Ohno and Maenaka, 2006). These results suggested that the roof greening with soil could reduce the room air temperature resulting from the latent heat (evaporative cooling) due to the evaporation from the soil and the soil may become as thermal insulator.

On the other hand, Tsuji et al. (2008) reported that the suppression of temperature rise became high with increasing the evapotranspiration from the roof greening. The cooling effect increased with increase in leaf area per unit roof area (LAI) in summer (Takakura et al., 2000; Jaffal et al., 2012). In greening type 1 (light interception ratio= 0.6), effect of coefficient of transpiration from the plants on diurnal changes of room air temperature was examined. As shown in Fig. 7, the room air temperature was decreased with increasing the coefficient of transpiration from the plants. When the coefficient of transpiration was 0 , room air temperature was increased to $36^{\circ} \mathrm{C}$ which was higher than ambient temperature. Since the coefficient of transpiration from the plants was contributed to reduce the room air temperature, the characteristics of transpiration from the plants may be important factor for reducing heat-island effect. Furthermore, the reduction in surface temperature on the soil was reported to vary with the varieties of plants and soil, thickness of the soil, and irrigation frequency (Onmura et al., 2001; Yamada et al., 2004; Arima et al., 2005; Yamaguchi et al., 2005; Ono et al., 2006), the simulation model included the characteristics of the plants, soil, and irrigation might be needed in further study.

Effect of light interception ratio of roof greening on the maximum room air temperature was shown in Fig. 8. In greening type 1 , the point that light interception ratio is 0 means the same condition of the soil without plants. In greening type 2 , the point that light interception ratio is 0

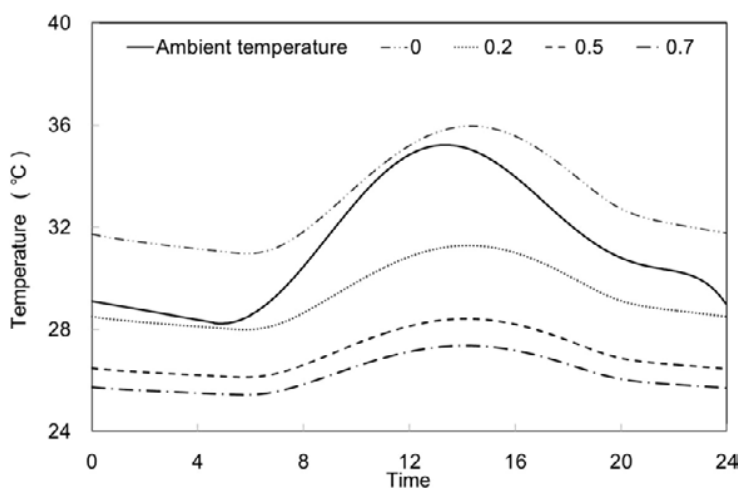

Fig. 7 Effect of transpiration coefficient from plants of roof greening on room air temperature with greening type 1 (Light interception ratio $=0.6$ ). Greening type 1 consists of plants with soil. means the same condition of no greening. The maximum room air temperature was decreased with increasing the light interception ratio. With greening type 1, the maximum room air temperature was lower compared with that with greening type 2. Decrease in room air temperature with increasing light interception ratio in greening type 2 was larger than that in greening type 1 .

Economical evaluation of roof greening for cooling

The effect of roof greening on cooling load was examined. The effect of light interception ratio on daily cooling load with set temperatures for air-conditioning at 24, 26, and $28^{\circ} \mathrm{C}$ was shown in Fig. 9. Daily cooling load was decreased with increase in light interception ratio. Daily cooling load with greening type 1 was lower than that with greening type 2 . This result suggested that the roof greening with soil can decrease daily cooling load compared with that without soil.

The points that light interception ratio is 0 in greening type 1 and greening type 2 mean the same condition of the soil without plants and no greening, respectively. In greening type 1, the roof greening with soil and without plants saved daily cooling load by about $80 \%$ compared with no

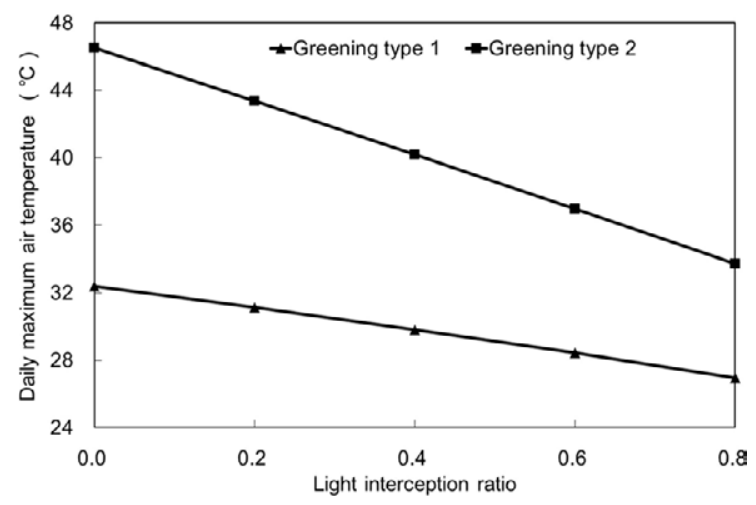

Fig. 8 Effect of light interception ratio on daily maximum air temperature in the room with two roof greening types. Greening type 1 consists of plants with soil. Greening type 2 consists of plants without soil.

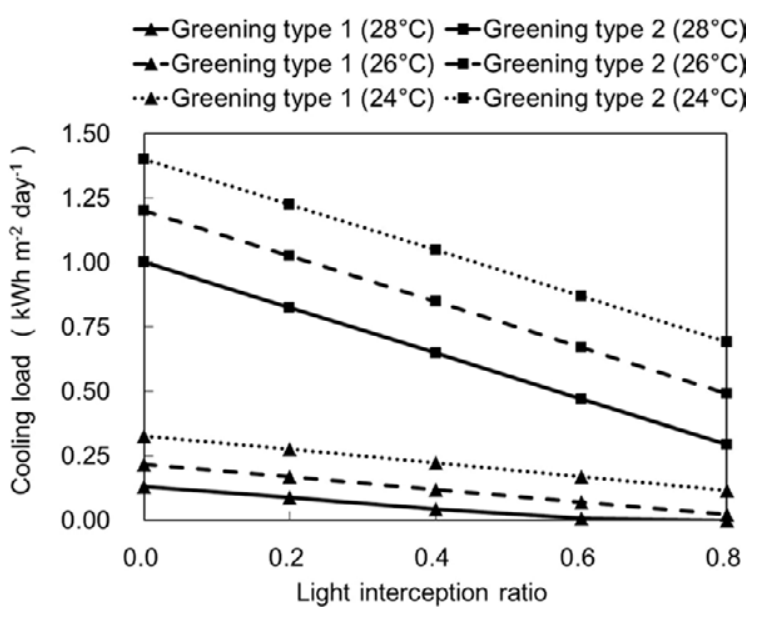

Fig. 9 Effect of light interception ratio on daily cooling load with two greening types at different cooling set temperatures $\left(24,26\right.$, and $\left.28^{\circ} \mathrm{C}\right)$. Greening type 1 consists of plants with soil. Greening type 2 consists of plants without soil. 
greening. In greening type 2 , the roof greening with plants for light interception ratio of 0.8 saved daily cooling load about $0.7 \mathrm{kWh} \mathrm{m}^{-2}$ day $^{-1}$ compared with no greening.

When air-conditioning turning on with set temperature of $26^{\circ} \mathrm{C}$, the monthly electricity cost was 144 yen for no greening, 8.4 yen for greening type 1 and 80.4 yen for greening type 2 (light interception ratio $=0.6$ ). Our result showed that electricity cost in warehouse for airconditioning in summer was saved with roof greening and this economic effect was greater with the roof greening system consists of plants and soil. Vijayaraghavan et al. (2012) reported that roof greening with soil reduced both heating and cooling as thermal insulator. The simulation model for roof greening evaluation in winter will be required in further study.

\section{CONCLUSIONS}

The effects of two roof greening systems with and without soil on room air temperature and cooling load in warehouse in summer were evaluated using a simulation model. Our results showed that the room air temperature with roof greening with soil was lower than that with roof greening without soil. The room air temperature was decreased with increasing the coefficient of transpiration from the plants. The maximum room air temperature was decreased with increasing the light interception ratio and decrease in room air temperature with increasing light interception ratio in greening with soil was larger than that in greening without soil.

The effects of roof greening on cooling load and electricity cost were investigated when the air-conditioning was turning on in summer. Daily cooling load of greening with soil was lower than that of greening without soil. The electricity cost in warehouse for air-conditioning in summer was saved with roof greening and this economic effect was greater when the roof greening system consists of plants and soil. The roof greening with soil could reduce the room air temperature resulting from the latent heat (evaporative cooling) due to the evaporation from the soil and the soil may become as thermal insulator.

\section{REFERENCES}

Arima, S., Suzaki, Y., Wakui, S., Yuji, M., Iijima, K. 2005. On the insulating effect and air temperature moderation by planting form in rooftop gardening. J. Jpn. Inst. Landsc. Architect. 68: $499-502$.
Iijima, K. 2008. Roof planting for various purpose of use and the plants. J. Jpn. Soc. Reveget. Tech. 34: 338-343.

Jaffal, I., Ouldboukhitine, S. E., Belarbi, R. 2012. A comprehensive study of the impact of green roofs on building energy performance. Renew. Energy 43: 157-164.

Miyagawa, J., Kawaguchi, M. 2002. A study on the design methods of roof greenery. Shizuoka Univ. Art Cult. Bull. 3: 131-139.

Nojima, Y., Okinaka, T., Seto, H., Kurayama, C., Nikaidou, M., Takasuna, H. 1995. Practical study on the effect of the plants on the roof of a building to reduce the heat absorption of the building and the urban area. J. Jpn. Soc. Reveget. Tech. 20: $168-176$.

Ohno, T., Maenaka, H. 2006. Temperature fluctuation of Sedum, Zoysia and surface in relation to evapo-transpiration and light spectrum using thin layer greening method. J. Jpn. Soc. Reveget. Tech. 32: 86-91.

Onmura, S., Matsumoto, M., Hokoi, S. 2001. Study on evaporative cooling effect of roof lawn gardens. Energy Build. 33: 653-666.

Ono, K., Yanagi, M., Kudo, T.,Teshirogi, J., Koshimizu, H. 2006. Evapotranspiration rate of rooftop gardening plants. J. Jpn. Soc. Reveget. Tech. 32: 74-79.

Satou, K., Yoshinaga, M., Hiruma, N., Noda, M., Isawa, T., Kanai, S., Okumiya, M. 2006. Study on the greening method of field-plate roof of industrial plants-Field measurement in thermal performances with four roof models. Architect. Inst. Jpn. 44: 421-424.

Santamouris, M. 2012. Cooling the cities - A review of reflective and green roof mitigation technologies to fight heat island and improve comfort in urban environments. Solar Energy. DOI: 10.1016/j.solener.2012.07.003

Tachibana, D., Naoki, S., Kikuchi, S., Maki, T., Sato, Y., Umazume, D., Imai, K. 2010. Trial application of factory rooftop greening system with ultra-lightweight substrate. J. Technol. Des. 16: 411-414.

Takakura, T., Kitabe, S., Goto, E. 2000. Cooling effect of greenery cover over a building. Energy Build. 31: 1-6.

Tsuji, M., Hiratsuka, A., Sano, Y., Suzuki, S. 2008. Controlling rising temperatures using Carex thunbergii Steud. For rooftop greening. J. Jpn. Soc. Reveget. Tech. 34: 375-383.

Yamada, H. 2008. An improvement of city environment by the building greening, and future view. J. Jpn. Soc. Reveget. Tech. 34: 333-337.

Yamada, H., Yabu, S., Nakashima, A., Nakano, S. 2004. Analysis for the heat insulation property of roof greening. J. Jpn. Inst. Landsc. Architect. 67: 453-456.

Yamaguchi, T., Yokoyama, H., Ishii, K. 2005. Mitigating the urban heat island effect by light and thin rooftop greening. J. Jpn. Inst. Landsc. Architect. 68: 509-512.

Vijayaraghavan, K., Joshi, U. M., Balasubramanian, R. 2012. A field study to evaluate runoff quality from green roofs. Water Res. 46: 1337-1345. 